\title{
IDENTIFICATION OF COMPOUND CHANNEL FLOW PARAMETERS
}

\author{
HABIB ABIDA
}

Department of Earth Sciences, Faculty of Science, Sfax, Tunisia.

Present address: Département des Sciences de la Terre, Faculté des sciences de Sfax, Route Sokra, km 3,5 BP 802, 3018 Sfax, Tunisia ; Tel.: 21698952 472, Fax: 21674274 437, mailto: habib.abida@voila.fr

Optimization methods are used to estimate parameters required for routing floods through open compound channels. Besides initial and boundary flow conditions, data required especially include, crosssectional area $(A)$ of flow and conveyance $(K)$ as functions of flow depth $(y)$ for a representative crosssection of the study reach. Thus, instead of optimizing upon channel's geometric and hydraulic parameters, optimization is performed upon non-physical parameters in assumed $A(y)$ and $K(y)$ relationships. The optimization method selected for this application is the Nelder and Mead Simplex Algorithm. The objective function is expressed in terms of the relative differences between observed and simulated stages and discharges, which are evaluated based on the complete numerical solution of St Venant equations. This approach to formulating the optimization problem was applied to unsteady flow data sets for an experimental reach of the River Main in Northern Ireland. Based on statistical analysis, simulated and observed stages were found to be in good agreement.

KEY WORDS: Compound Channel, Flood Routing, Unsteady Flow, Optimization.

Habib Abida: IDENTIFIKÁCIA PARAMETROV ZLOŽENÝCH KANÁLOV. J. Hydrol. Hydromech., 57, 2009, 3; 18 lit., 4 obr., 2 tab.

Parametre potrebné pre kvantifikáciu transformácie povodňových vĺn v otvorených, zložených kanáloch, boli určené optimalizačnou metódou. Okrem počiatočných a okrajových podmienok sú potrebné d'alšie údaje, vrátane plochy priečneho rezu prúdom $(A)$, ako aj vodivost' časti toku $(K)$ ako funkcie híbky $(y)$ pre reprezentatívny priečny rez. Namiesto optimalizácie geometrických a hydraulických parametrov kanála, optimalizácia sa vykonala pre nefyzické parametre, predpokladajúc závislosti $A(y)$ a $K(y)$. Vybranou metódou optimalizácie je Nelderov a Meadov Simplex Algoritmus.

Funkcia je vyjadrená pomocou relatívnych rozdielov medzi pozorovanými a simulovanými vodnými stavmi a prietokmi, ktoré boli vyčíslené numerickým riešením rovníc St. Venanta. Tento spôsob formulácie optimalizačného problému bol aplikovaný na údaje pre neustálené prúdenie v experimentálnom priamom úseku rieky Main (River Main) v Severnom Írsku. Štatistickou analýzou bolo zistené, že simulované a merané vodné stavy boli vel'mi blízke.

KLÚČOVÉ SLOVÁ: zložený kanál, transformácia povodňovej vlny, neustálené prúdenie, optimalizácia.

\section{Introduction}

Unsteady open channel flow modelling is used in flood routing and prediction, stream flow modelling and river regulation, and in the analysis of estuarine flow phenomena. In such studies good estimates of stage and discharge require not only a reliable unsteady flow model but also adequate data for the flood routing application. The data consist mainly of the river cross-section geometry and appropriate boundary roughness coefficients, in addition to initial and boundary flow conditions (water levels and discharges) as well as hydraulic structure information.

Obtaining these data usually implies extensive field surveys, which can make a numerical modelling application extremely expensive. On the other hand, the accuracy gained by using the complete St. Venant equations would suffer if inadequate or suspect data were used. A possible alternative procedure, that could significantly reduce the necessary quantity of data, is one employing optimization techniques. In this approach an objective function, representing the difference between simulated and observed values of discharge or flow depth, is 
minimized to yield the optimization model parameters, which represent, in fact, data required for the flood routing application.

Optimization techniques were successfully used by Becker and Yeh (1972, 1972a), Fread and Smith (1978) and Wormleaton and Karmegam (1984) to identify parameters for regular prismatic channels having simple cross-sections. These researchers used the same optimization algorithm (the so-called "Influence Coefficient" Algorithm) which, mathematically, is closely related to both quasilinearization and the gradient method.

Khatibi et al. (1997) used a nonlinear least square technique with three types of objective function and identified open channel friction parameters by a modified Gauss-Newton method. Atanov et al. (1999) used Lagrangian multipliers and a least square errors criterion to estimate roughness coefficients. More recently, Ding et al. (2004) used the quasi-Newton method to identify Manning's roughness coefficients in shallow water flows. Nevertheless, the above studies considered only the case of in-bank flow. Therefore, there is a need to extend the method to out-bank flow, where flood plain roughness will obviously have to be considered.

One of the very few studies which dealt with the identification of compound channel flow parameters is the one by Nguyen and Fenton (2005). In this study, roughness coefficients in the main channel and flood plains were identified as two different parameters using an automatic optimization method. The model was applied to Duong River in Vietnam, where roughness coefficients of the main channel and the flood plain were presented as different constant values as well as polynomial functions of stage.

In this study the Simplex method is used in an optimization model to estimate the parameters required for routing floods in the River Main in Northern Ireland. The solution of the unsteady flow equations requires only cross-sectional area $(A)$ and conveyance $(K)$ as functions of flow depth $(y)$. Thus, instead of the conceptual approach of optimizing upon a channel's geometric and hydraulic parameters, optimization was performed upon nonphysical parameters in assumed $A(y)$ and $K(y)$ relationships. These relationships speed up the numerical solution of the unsteady flow equations. Furthermore, the relative simplicity of the relationships reduces necessary computer time and computer storage requirements because much less computations are involved.
'RUFICC', the numerical model used in this application, was developed specifically for routing flood flows through compound channels, i.e. river channels with flood plain zones (Abida, 1992). Unlike other similar models, which usually treat flood plain zones of rivers as 'storage', RUFICC attempts to account for flood plain contributions to system conveyance.

\section{Unsteady flow model}

The unsteady flow model used is RUFICC (Routing Unsteady Flows In Compound Channels), a one dimensional model that uses a modified version of St. Venant equations (Abida, 1992 and Abida and Townsend 1994). The model, which was validated using extensive laboratory and field data, accounts for flood plain contributions to system conveyance and also for lateral momentum transfer between adjacent deep and shallow zones of compound flow fields.

The continuity equation is written as:

$$
\frac{\partial A}{\partial t}+\frac{\partial Q}{\partial x}-q=0
$$

where $A$ - cross-sectional area of flow $\left[\mathrm{m}^{2}\right], Q-$ discharge $\left[\mathrm{m}^{3} \mathrm{~s}^{-1}\right], q$ - lateral discharge $\left[\mathrm{m}^{2} \mathrm{~s}^{-1}\right], t-$ time [s], and $x$ - longitudinal distance along channel $[\mathrm{m}]$.

The equation of motion is:

$$
\begin{aligned}
& \frac{\partial Q}{\partial t}+2 M_{f} \frac{Q}{A} \frac{\partial Q}{\partial x}-M_{f} \frac{Q^{2}}{A^{2}} \frac{\partial A}{\partial x}+ \\
& +\frac{Q^{2}}{A} \frac{\partial M_{f}}{\partial x}+g A\left(\frac{\partial H}{\partial x}\right)+g F Q^{2}-u q=0,
\end{aligned}
$$

where $\mathrm{g}$ - acceleration due to gravity $\left[\mathrm{m} \mathrm{s}^{-2}\right], H-$ water surface elevation $[\mathrm{m}], u$ - velocity of lateral inflow in the $x$-direction $\left[\mathrm{m} \mathrm{s}^{-1}\right], M_{f}-$ a momentum correction factor given by:

$$
M_{f}=\frac{A_{m}+A_{p}}{\left(K_{m}+K_{p} \eta^{1 / 2}\right)^{2}}\left(\beta_{m} \frac{K_{m}^{2}}{A_{m}}+\beta_{p} \eta \frac{K_{p}^{2}}{A_{p}}\right)
$$

and $F$ is a coefficient, defined as:

$$
F=\frac{A_{m}+\eta A_{p}}{\left(K_{m}+K_{p} \eta^{1 / 2}\right)^{2}} .
$$


In Eqs. (3) and (4) subscripts $m$ and $p$ refer to the main channel and flood plain sub-sections respectively, $K$ - conveyance, $\beta$ - Boussinesq or momentum correction factor, and $\eta-\mathrm{a}$ coefficient that accounts for the dynamics of flood-plain flow.

Bhowmik and Demissie (1982) show that flood plain flows are a function of compound channel geometry and the flood return period and, in the case of extreme flood events, the flood plain component can be as large as the main channel flow. They also demonstrate that, in general, when flood plain depths exceed $35 \%$ of the main channel depth, the composite channel can be treated as a single unit. While RUFICC accounts for flood plain contributions to system conveyance, because velocities are generally much higher in the main channel than elsewhere, different friction slopes are assigned to the main channel and flood plain zones. The main channel friction slope is assumed equal to that of the composite section while the flood plain friction slope is given as:

$S_{f p}=\eta S_{m f}$,

where

$\eta=\frac{1}{2}\left(1-\cos \frac{\pi y_{r}}{0,35}\right)$ when $y_{r} \leq 0.35$

and $\eta=1 \quad$ for $y_{r} \succ 0.35$

where $y_{r}$ - flood plain to main channel depth ratio.

Flood routing through compound channels is accomplished by solving Eqs. (1) to (4). Eqs. (1) and (2) are non-linear partial differential equations and are solved numerically. The weighted four-point implicit finite-difference scheme (Amein and Fang, 1970) was selected for this application.

\section{Optimization model}

\section{The Nelder and Mead simplex method}

The geometric figure formed by a set of $m+1$ points in $m$-dimensional space is called a "simplex". The basic premise in the simplex method is to compare the values of the objective function in the $m+$ 1 vertices of a general simplex and move this simplex gradually towards the optimum point in the iterative process. For further information on the Simplex method the reader is referred to Wilde and Beightler (1967).

\section{Objective function}

As in any optimization problem an objective function $F_{o}$, which includes all parameters to be estimated, must be specified. For the present (unconstrained) optimization problem the objective function should include the differences in depth and discharge between observed and simulated outflow hydrographs. The relative errors at the $j^{\text {th }}$ time increment can be defined as: $E_{h}^{j}=\frac{H_{O}^{j}-H_{c}^{j}}{H_{O}^{j}}$ and $E_{q}^{j}=\frac{Q_{o}^{j}-Q_{c}^{j}}{Q_{o}^{j}}$ where subscripts $c$ and $o$ refer to 'calculated' and 'observed' values respectively. Two broad classes of objective function can be considered (Wormleaton and Karmegam, 1984):

$\operatorname{Minimize} F_{0}=\operatorname{Max}\left(\left|E_{h}^{j}\right|+\left|E_{q}^{j}\right|\right)$

or:

$\operatorname{minimize} F_{0}=\sum_{j=1}^{m}\left(\left|E_{h}^{j}\right|+\left|E_{q}^{j}\right|\right)^{2}$.

Eq. (7) represents the "minimax" criterion, which is particularly suitable when the error at a critical time is of interest (e.g. peak discharge or depth). The least-square criterion, represented by Eq. (8), was adopted in this study because it was considered more important that depth and discharge be modelled correctly over the entire hydrograph. Furthermore, Nguyen and Fenton (2004) investigated the effect of three main types of objective function and showed that least square objective function had the best performance.

Using the Simplex method the objective function was evaluated at the vertices of the simplex and the variance of these objective function values was estimated. The convergence criterion to be satisfied before terminating the optimization procedure is based on comparing actual variance to a critical value $\left(10^{-10}\right.$ in this application). If the former is less than or equal to the latter, the optimization procedure terminates and the desired minimum is reached.

\section{Model parameters}

The optimization model parameters, i.e. parameters estimated using optimization methods, are ab- 
stract parameters in assumed $A(y)$ and $K(y)$ relationships, of the form:

$$
A_{i}=a_{i} y_{i}^{b_{i}}
$$

and

$$
K_{i}=c_{i} y_{i}^{d_{i}},
$$

where $y$-flow depth, $a, b, c$, and $d$ - real constants, and $i-m$ or $p$, referring to the main channel and flood plain sub-sections respectively. In this formulation conveyance appears to be a function of depth only; however the effect of boundary roughness is incorporated in the constant $c$. To simplify the problem and reduce the number of real constants requiring estimation through the optimization process, the flood plains were approximated with rectangular cross-sections, the condition under which $b_{p}=1$. Furthermore, since flood plain depth is generally very much smaller than the section width, the flood plain wetted perimeter $\left(W_{p}\right)$ can be approximated by the section width $\left(a_{p}\right)$. Substituting $A_{p}$ by $a_{p} y_{p}$ and $W_{p}$ by $a_{p}$ in the flood plain conveyance relationship yields:

$$
K_{p}=\frac{A_{p}}{n_{p}} R_{p}^{2 / 3}=\frac{a_{p}}{n_{p}} y_{p}^{5 / 3}=c_{p} y_{p}^{5 / 3} .
$$

Comparing Eqs. (10) and (11), it can be clearly seen that $d_{p}=5 / 3$. This brings the number of parameters for the representative cross-section of the study reach to six, namely $a_{m}, b_{m}, c_{m}, d_{m}, a_{p}$, and $c_{p}$.

Compared to the conceptual optimization method, the assumed $A(y)$ and $K(y)$ relationships speed up the computations involved in solving the unsteady flow equations, as less computations are involved. Furthermore, their relative simplicity reduces necessary computer time and required computer storage. The time required for a single objective function evaluation on an AMDAHL 5680 main frame computer was reduced from 52 to 16 seconds, when the proposed formulation replaced the conceptual approach. Finally, the suggested method also avoids the use of roughness coefficients available in the literature, which are based on steady uniform flow conditions. The use of these roughness coefficients for unsteady flow analysis is only an approximation. Yen (1986) reported that the value of $\mathrm{n}$ for unsteady non-uniform open channel flow, which has not yet theoretically been established, depends on boundary roughness, Reynolds number, Froude number and unsteadiness and non-uniformity of the flow.

\section{Simulations and results}

Model validation included in the main study relied on both laboratory and field data sets (Abida, 1992). However, only the case study using field data is reported herein. This study involved routing flood hydrographs along a reach of the River Main in Northern Ireland. The data set for this simulation included:

1. cross-sectional details at the upstream end, in the middle, and at the downstream end of the study reach. The dimensions of the middle (representative) cross-section are shown in Fig. 1;

2. stage-discharge curves for the upstream and downstream stations;

3. time histories of depths at the upstream and downstream stations;

4. Manning's roughness coefficient $\mathrm{n}$ as a function of flow depth in the main channel and in the flood plain sub-sections. Manning's $n$ was estimated for the different sub-sections of the compound flow field based on velocity traverses used to compute component discharges.

Myers' study reach was $800 \mathrm{~m}$ long with an average bed slope of $0.3 \%$. The more or less symmetrical compound cross-section (Fig. 1) had two flood plains of almost the same widths as the main channel, whose bank-full depth varied between 0.95 and $1.05 \mathrm{~m}$. The depth-time series at the upstream station were used as the upstream boundary condition. The downstream boundary condition was determined from the stage-discharge curve provided in the data set and the selected time step and space increment were $1500 \mathrm{~s}$ and $400 \mathrm{~m}$ respectively. This choice of mesh size satisfies the 'accuracy' criterion (Wormleaton and Karmegam 1984) when the four-point implicit finite difference scheme of Amein and Fang (1970) is employed. The study reach was assumed prismatic and, although the flood plain cross-sections had mild transverse slopes, these were treated as rectangular sections on horizontal planes.

Since only one time series of depths was made available to this study, this was divided into two segments. One part, corresponding to the first registered hydrograph, was used in the optimization process to evaluate the flood routing parameters. The other part was used to check the accuracy of the optimum parameters obtained by comparing simulated downstream depths with observed data. The application reported in this paper used stages only in the objective function formulation simply 


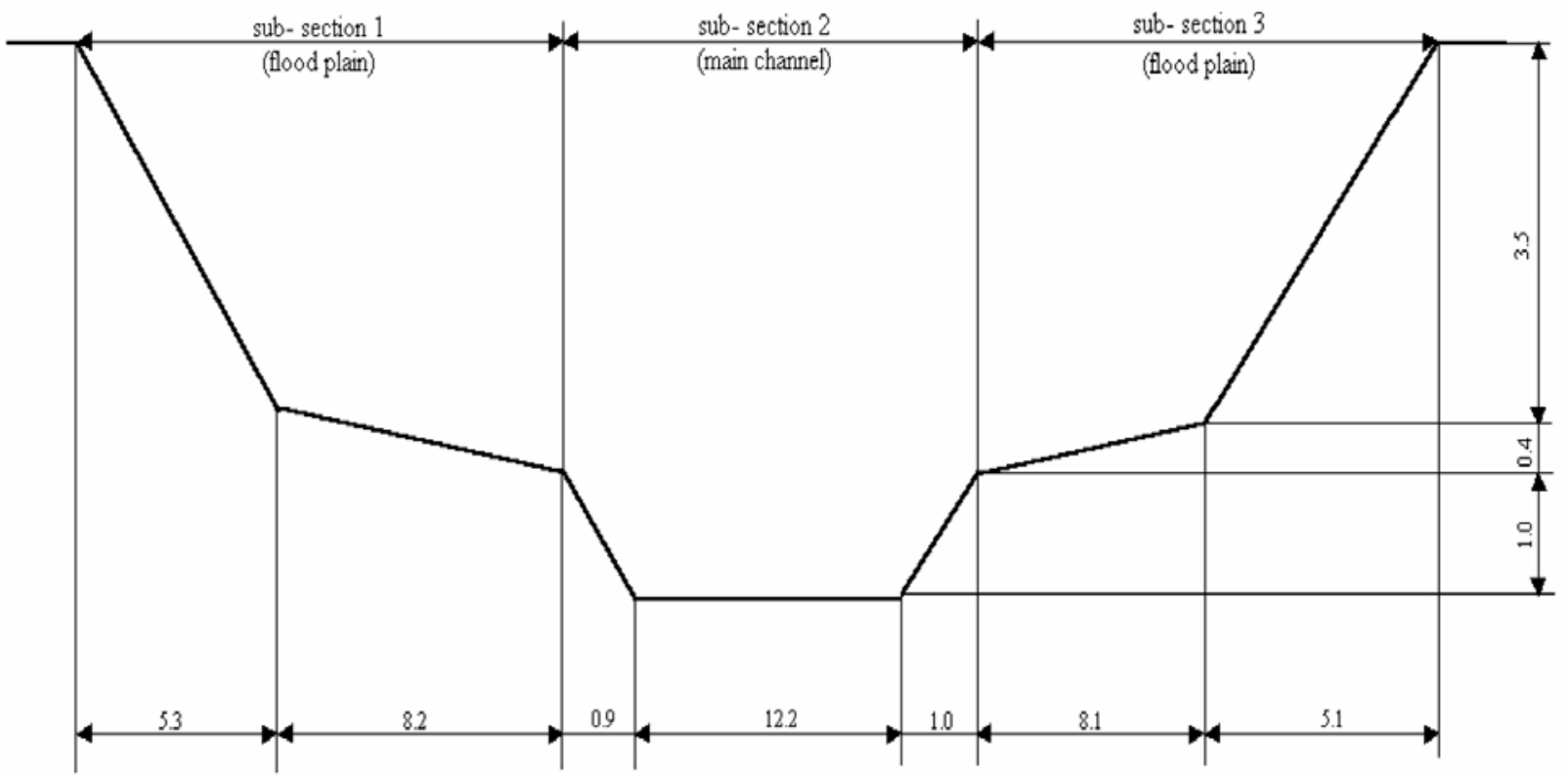

Fig. 1. Middle (representative) cross-section of the River Main study reach, Northern Ireland (not to scale, all dimensions in meters).

Obr. 1. Priemerný (reprezentatívny) priečny rez priameho úseku rieky Main, Severné Írsko (nie je v mierke, všetky rozmery sú $\mathrm{v}$ metroch).

because discharges obtained based on measured water stages and rating curves (established for steady flow condition) are not valid for unsteady flow regime. Nevertheless, discharge relative errors may be considered in other applications provided that measured discharges are obtained directly (without using water stages) and for unsteady flow regime. This may seem impractical, but new techniques for direct velocity and discharge measurements do exist.

A set of initial estimate for the optimization model parameters was arbitrarily selected. However, a good approximation of the optimization model parameters can be obtained based on a rough inspection of the channel geometry and a crude estimation of Manning's coefficient, depending on natural roughness conditions and tables and flowcharts, available in the literature (Chow, 1959 and Henderson, 1971 among others). Initial values, together with optimum parameters obtained from the optimization process, are shown in Tab. 1. As noted in the table, the objective function value was reduced from 12.53 to 0.1105 in 23 iterations. It is important to note at this stage that initial estimates do not affect the final outcome of the optimization process, but may only influence the total number of iterations required for convergence.

Referring again to Tab. 1, the resulting equations for main channel and flood plain cross-sectional area and system conveyance are given respectively as:

$$
\begin{aligned}
& A_{m}=11.908 y_{m}^{0.912,} \\
& A_{p}=6.847 y_{p}, \\
& K_{m}=383.6 y_{m}^{1.863}, \\
& K_{p}=81.4 y_{p}^{1.667} .
\end{aligned}
$$

$\mathrm{T}$ a b l e 1. Optimization features for River Main reach. $\mathrm{T}$ a b u l' k a 1 . Optimalizácia podmienok pre priamy úsek toku Main; 1 - optimalizačný parameter, 2 - zvolená hodnota, 3 - optimálna hodnota.

\begin{tabular}{ccc}
\hline $\begin{array}{c}\text { Optimization } \\
\text { parameter/feature }\end{array}$ & $\begin{array}{c}\text { Trial } \\
\text { value }^{2)}\end{array}$ & $\begin{array}{c}\text { Optimal } \\
\text { value }^{3)}\end{array}$ \\
\hline Variance & - & $0.3910^{-4}$ \\
$F_{o}$ & 12.53 & 0.1105 \\
No. of iter & - & 23 \\
$a_{m}$ & 12.0 & 11.908 \\
$b_{m}$ & 1.0 & 0.912 \\
$c_{m}$ & 300.0 & 383.6 \\
$d_{m}$ & 1.5 & 1.863 \\
$a_{p}$ & 6.5 & 6.847 \\
$c_{p}$ & 80.0 & 81.40 \\
\hline
\end{tabular}

Accuracy and reliability of the parameters identified through the optimization process were tested 
by routing the complete time series of depths using Eqs. (11) to (14) to represent the main channel and flood plain cross-sectional area and conveyance terms. Simulated and observed stages at the downstream end of the study reach are shown in Fig. 2. Comparison between the two time series indicates reasonably good agreement.

Unsteady flow simulations were repeated based on actual measured data of channel geometry and boundary roughness, instead of using the optimization model parameters as input to the flood routing model. Manning's $\mathrm{n}$ varied from 0.05 near the boundary to 0.04 near the surface for the in-bank flow. Over-bank main channel flow is characterized by a practically constant Manning's coefficient of 0.038 . Finally, the floodplain sub-section had a Manning's roughness coefficient varying with depth from 0.05 to 0.032 , reached at a depth of $2.2 \mathrm{~m}$, with respect to the main channel bottom. These data were obtained by taking measurements of velocity traverses that served in computing component discharges of the different sub-sections of the compound flow field. Nevertheless, measurements were taken under a 'steady flow' condition and are not necessarily valid for 'unsteady flow' computations.

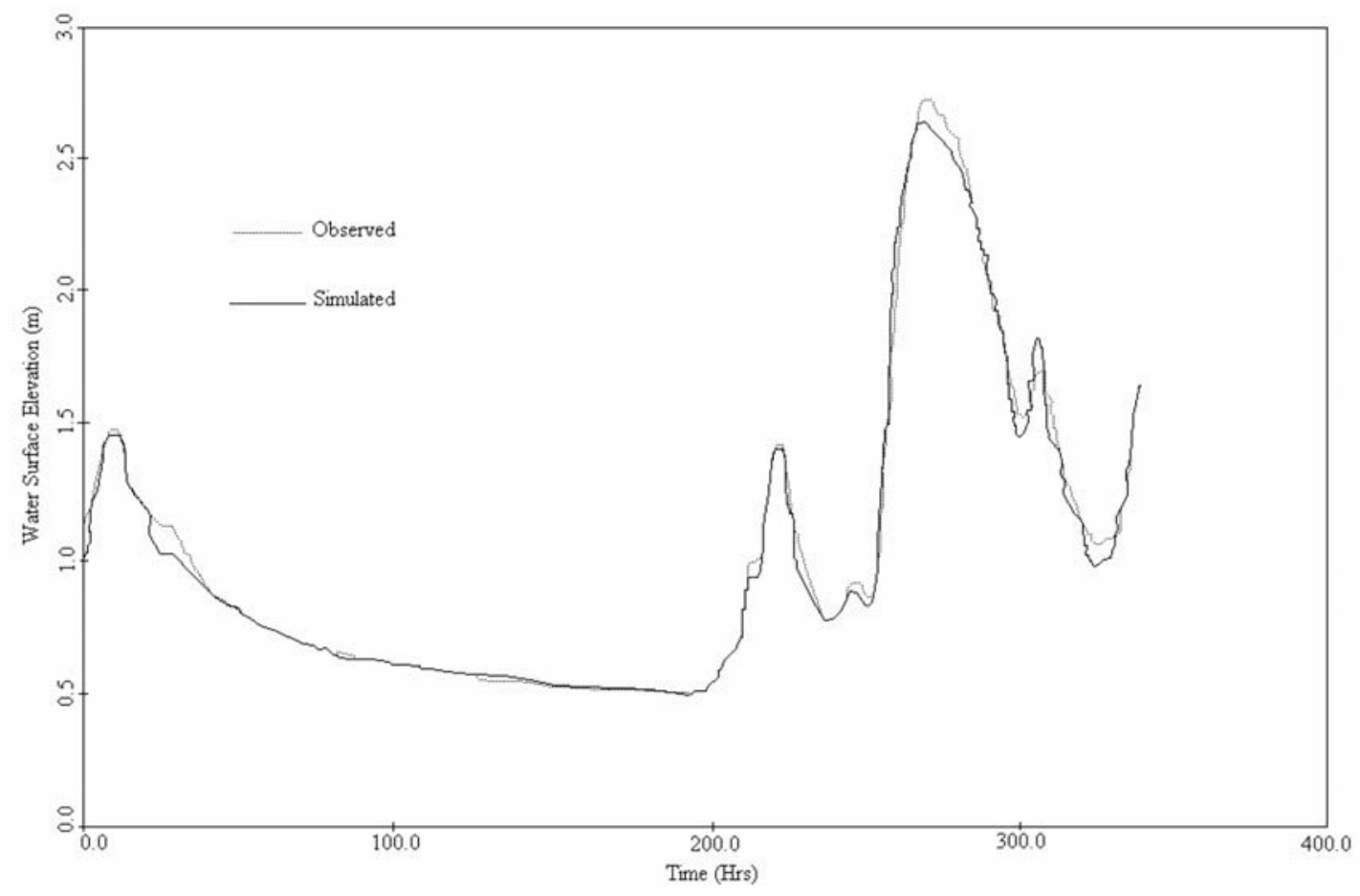

Fig. 2. Observed versus simulated stage hydrographs for the River Main reach, (optimal data).

Obr. 2. Merané versus simulované vodné stavy v priamom úseku rieky Main, (optimálne hodnoty).

Results of the unsteady flow simulation based on actual data are displayed in Fig. 3, which shows a reasonably good agreement between observed and simulated water levels. Nevertheless, it is also evident form the same figure that simulated stages are consistently slightly underestimated. This would imply that if different values of Manning's roughness coefficient were adopted, a better agreement between observed and simulated stages could be achieved.

A third simulation, which used actual measured channel geometry and a pre-calibrated Manning's roughness coefficient, was considered. A single (average) value of Manning's $\mathrm{n}$ was assigned to both the main channel and the flood plain, based on a trial and error procedure that resulted in the closest agreement between observed and simulated stages. The same part of the time series used in the optimization model was considered in this calibration process, which yielded a value of 0.036 for Manning's $\mathrm{n}$. The corresponding simulated stages are shown in Fig. 4. Comparing Figs. 2, 3 and 4, it is clear that simulated stage hydrographs based on optimal data (Fig. 2) and a pre-calibrated Man- 
ning's n (Fig. 4) are comparable, and show a better performance compared to the simulation based on actual data (Fig. 3).

Instead of relying exclusively on visual impressions of the correspondence between simulated and observed hydrographs, which can be quite subjective, a statistical analysis was performed to test the agreement between the two. The statistics considered are: (i) the sum of squared residuals (SSR), (ii) standard error of estimate (SEE), (iii) correlation coefficient (Rso), and (iv) the modified correlation coefficient (MRso), which is weighted by the ratio of standard deviations of observed and simulated time series (McCuen and Snyder, 1975). Statistical parameters for the three simulations are displayed in Tab. 2, which shows that the highest SSR and SEE values are associated with the actual data application. On the other hand, even though the modified correlation coefficients were close to unity for all applications, the correlation coefficient was shown to be higher when a pre- calibrated Manning's n or optimal data were used.

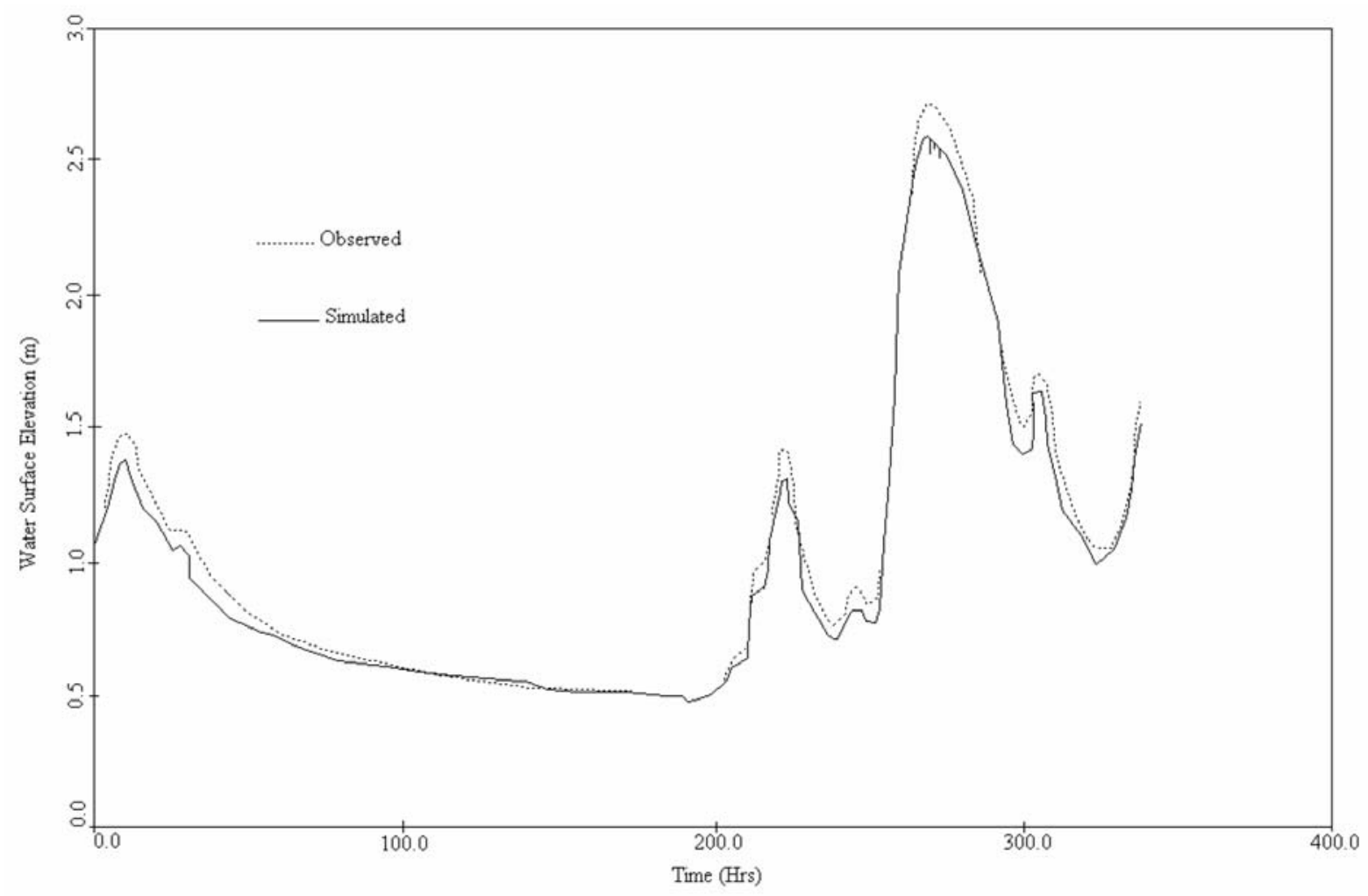

Fig. 3. Observed versus simulated stage hydrographs for the River Main reach, (actual data).

Obr. 3. Merané versus simulované vodné stavy v priamom úseku rieky Main, (aktuálne hodnoty).

$\mathrm{T}$ a b $1 \mathrm{e}$ 2. Statistical results.

T a b u l' k a 2. Štatistické výsledky; 1 - Skutočné hodnoty, 2 - predkalibrované podl'a Manninga, 3 - optimálne hodnoty, 4 suma rezíduí štvorcov, 5 - štandardná odchýlka, 6 - koeficient korelácie, 7 - modifikovaný koeficient korelácie.

\begin{tabular}{lccc}
\hline \multicolumn{1}{c}{ Statistic } & \multicolumn{3}{c}{ Data used } \\
\cline { 2 - 4 } & Actual data $^{1)}$ & Pre-calibrated Manning's n $^{2)}$ & Optimal data $^{3)}$ \\
\hline Sum of squared residuals $^{4)}$ & 2.704 & 1.596 & 1.497 \\
Standard error of estimate $^{5)}$ & 0.052 & 0.040 & 0.043 \\
Correlation coefficient $^{6}$ & 0.9564 & 0.9919 & 0.9891 \\
Modified correlation coefficient $^{7)}$ & 0.9996 & 0.9995 & 0.9988 \\
\hline
\end{tabular}




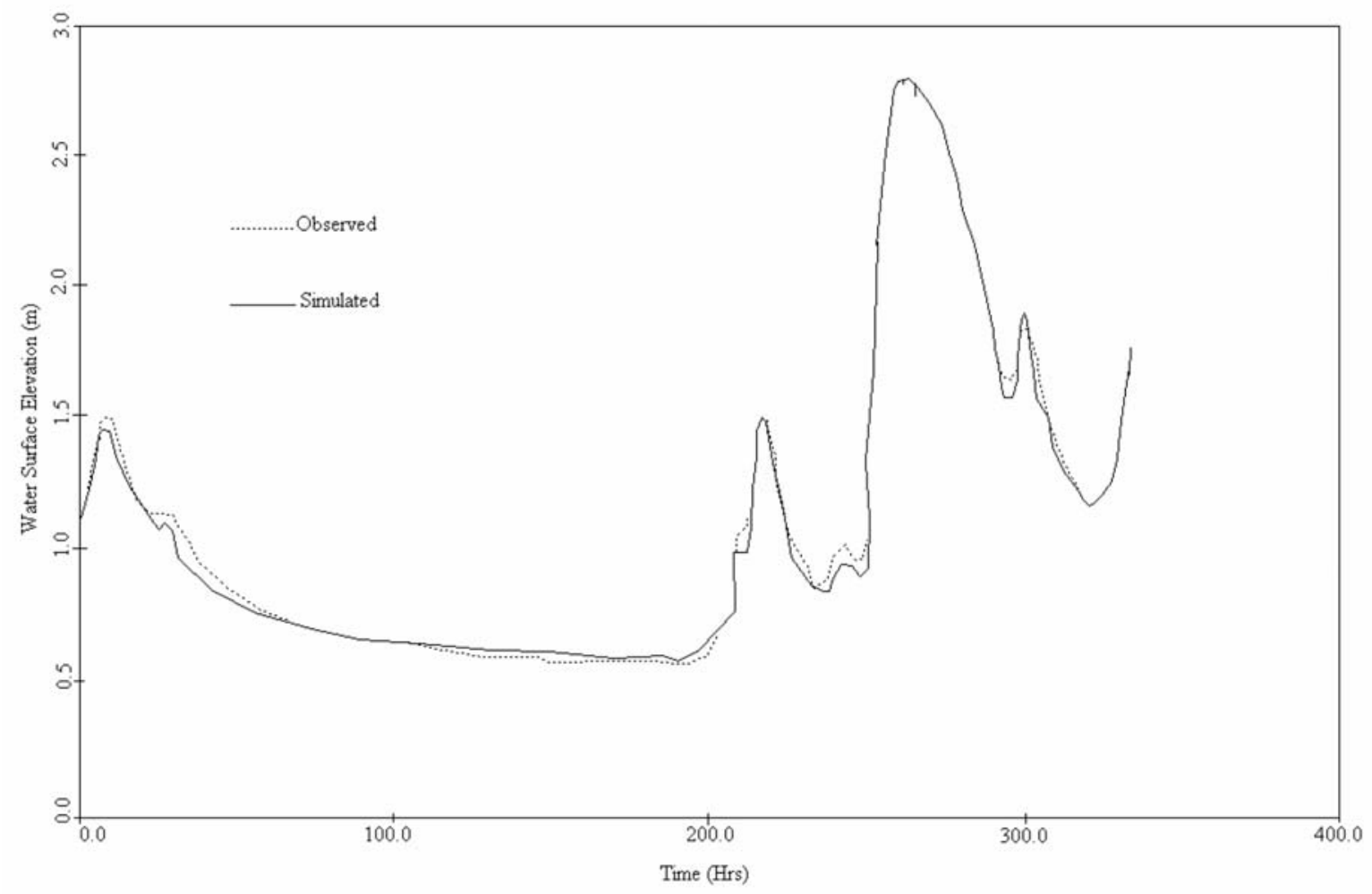

Fig. 4. Observed versus simulated stage hydrographs for the River Main reach, (pre-calibrated Manning 's roughness coefficient). Obr. 4. Merané versus simulované vodné stavy v priamom úseku rieky Main, (predkalibrované Manningove koeficienty drsnosti).

These results underscore the importance of calibrating unsteady flow models, especially in regards to the determination of Manning's roughness coefficient, before their application to a particular river reach. The calibration process largely depends on using appropriate values for the flow resistance coefficient. Manning's $\mathrm{n}$ cannot be measured directly and a great deal of uncertainty is usually associated with its estimation. For this particular application the values provided for Manning's $n$ were determined for a steady uniform flow condition. However, these values are not necessarily appropriate when the flow is unsteady. On the other hand, Fread and Smith (1978) showed that the value of Manning's n depends not only on discharge and flow depth but also on the particular schematization used to describe the continuous channel geometry by a series of discrete representations along the reach of channel being modelled. This leads to the conclusion that $\mathrm{n}$ is best evaluated through calibration of the unsteady flow model, especially if reasonably accurate field data from past flood events are available. Alternatively, the optimization approach presented in this paper directly yields cross-sectional area and conveyance relationships in terms of flow depth without having to estimate Manning's $n$.

\section{Conclusions}

Based on minimization of the error between simulated and observed stage hydrographs, the optimization approach yielded cross-sectional area $A(y)$ and conveyance $K(y)$ functional relationships, which were later tested by unsteady flow computations. Compared to observed stages, flood routing, based on the obtained $A(y)$ and $K(y)$ relationships, yielded reasonably good results. However, the optimized functions are valid only if the state of the watercourse remains unchanged. Indeed, these functional relationships should be re-optimized in case of change of the section geometry (e.g. an intended construction on a flood plain) or roughness (e.g. different seasonal vegetative cover) based on new measured stage and/or discharge time series.

The particular formulation of the objective function presented in this study is especially advantageous for compound channels because of the uncertainty associated with the development of the composite section conveyance. The method also avoids 
the use of steady flow roughness coefficients used in formulae such as Chezy's or Manning's to evaluate the friction slope terms in the unsteady open channel flow equations.

Accurate depth measurements, at the upstream and downstream ends of the River Main study reach, improved the estimate of the optimal flood routing parameters. However, errors in field data caused by imprecise measurement procedures and small sampling rates require that the user rely on several (rather than one) flood events in the optimization process.

Flood routing parameters estimation using optimization techniques should result in a saving of costs associated with detailed field surveys and should also improve the accuracy of numerical river models. Nevertheless, optimization methods could not possibly replace completely the collection of survey data. Their use is particularly advantageous in the case of fairly long, featureless and relatively inaccessible reaches of natural watercourses.

Acknowledgements. River Main data, used in the present study, were supplied by Robert Myers, University of Ulster at Jordanstown, N. Ireland.

\section{List of symbols}

$A$ - cross-sectional area of flow $\left[\mathrm{m}^{2}\right]$,

$C_{q}$ - a parameter in the unsteady flow equations,

$f$ - Friction coefficient,

$\mathrm{g}-$ acceleration due to gravity $\left[\mathrm{m} \mathrm{s}^{-2}\right]$,

$H$ - water surface elevation [m],

$I$ - ratio of the flood plain to the composite section friction slopes,

$K$ - conveyance $\left[\mathrm{m}^{3} \mathrm{~s}^{-1}\right]$

$M_{f}$ - momentum correction factor for the composite section,

$\mathrm{n}$ - Manning's roughness coefficient,

$P$ - wetted perimeter [m],

$Q$ - discharge $\left[\mathrm{m}^{3} \mathrm{~s}^{-1}\right]$,

$q$ - lateral discharge $\left[\mathrm{m}^{2} \mathrm{~s}^{-1}\right]$,

$r$ - ratio of flood plain to main channel hydraulic radii,

$S_{f}-$ friction slope $\left[\mathrm{m} \mathrm{m}^{-1}\right]$,

$S$ - channel bed slope $\left[\mathrm{m} \mathrm{m}^{-1}\right]$,

$t$ - time [s],

$W$ - sub-section width [m],

$x$ - distance along the channel [m],

$y$ - flow depth [m],

$\beta-$ momentum correction factor for individual sub-section,

$\lambda$ - coefficient to account for the lateral momentum transfer mechanism,

$\eta$ - coefficient to account for the dynamics of flood-plain flow.

\section{REFERENCES}

ABIDA H., 1992: Mathematical Modelling and Parameter Identification for Unsteady Flow in Compound Channels.
Ph.D. Thesis, University of Ottawa, Ottawa, Ontario, Canada.

ABIDA H. and TOWNSEND R.D., 1994: A Model for Routing Unsteady Flows in Compound Channels. Journal of Hydraulic Research, Vol. 32, No. 1, pp. 145-153.

AMEIN M. and FANG C.S., 1970: Implicit Flood Routing in Natural Channels. Journal of the Hydraulics Division, ASCE, Vol. 96, No. HY12, December, pp. 2481-2500.

ATANOV G.A., EVSEEVA E.G and MESELHE E.A., 1999: Estimation of Roughness Profile in Trapezoidal Open Channel. Journal of Hydraulic Engineering, 125, 3, 309-312.

BECKER L. and YEH W., 1972: Identification of Parameters in Unsteady Open Channel Flows. Water Resources Research, Vol. 8, No. 4, Aug., pp. 956-965.

BECKER L. and YEH W., 1972a: Optimal Identification of Resistance Parameters in Natural Channels. International Symposium on Systems Engineering and Analysis, Vol. II, Purdue University, West Lafayette, Indiana, October, pp. 36-40.

BHOWMIK N.G. and DEMISSIE M., 1982: Carrying Capacity of Flood Plains. Journal of the Hydraulics Division, ASCE, Vol. 108, No. HY3, March, pp. 443-453.

CHOW V.T., 1959: Open Channel Hydraulics. McGraw Hill Inc., New York, USA.

DING Y., JIA Y. and WANG S.S.Y., 2004: Identification of Manning's roughness Coefficient in Shallow Water Flows. Journal of Hydraulic Engineering, 130, 6, 501-510.

FREAD D.L. and SMITH G.F., 1978: Calibration Technique for 1-D Unsteady Flow Models. Journal of the Hydraulics Division, ASCE, Vol. 104, No. HY7, July, pp.1027-1044.

HENDERSON F.M., 1971: Open Channel Flow. Macmillan Publishing Co., Inc., New York.

KHATIBI, R.H., WILLIAMS, J.J.R. and WORMLEATON P.R., 1997: Identification Problem of Open Channel Friction Parameters. Journal of Hydraulic Engineering, 123, 12, 1078-1088.

McCUEN R.M. and SNYDER W.M., 1975: A Modified weighted Pearson coefficient. Water Resources Research, Vol. 11, No. 6, December.

NGUYEN T.H. and FENTON D.J., 2004: Identification of roughness in open channels. Proc. of $6^{\text {th }}$ International Conference on Hydro-Science and Engineering, Brisbane, Australia, June 2004.

NGUYEN H.T. and J.D. FENTON, 2005: identification of roughness for flood routing in compound channels. Proc. 31 st Congress, Int. Assoc. Hydraulic Eng. And Res., Seoul, Korea, 11-16 September 2005.

WILDE D.J. and BEIGHTLER C.S., 1967: Foundations of Optimization. Prentice-Hall, Inc., Englewood Cliffs, New Jersey, USA.

WORMLEATON P.R. and KARMEGAM M., 1984: Parameter Optimization in Flood Routing. Journal of Hydraulic Engineering, ASCE, Vol. 110, No. HY12, Dec., pp. 1799$-1814$.

YEN B.C., 1986: Hydraulics of Sewers. Advances in Hydroscience, Vol. 14, Academic Press Inc., Orlando, Florida, USA, pp. 1-115. 


\section{IDENTIFIKÁCIA PARAMETROV ZLOŽENÝCH KANÁLOV}

\section{Habib Abida}

Minimalizáciou chýb medzi simulovanými a vypočítanými úrovňami hladín umožnil optimalizačný prístup získat' funkčnú závislost' medzi plochou priečneho rezu vodného prúdu $A(y)$ a jeho vodivost'ou $K(y)$; táto závislost' bola d’alej testovaná výpočtom neustáleného prúdenia. Vypočítaná transformácia povodňovej vlny založená na funkčných závislostiach $A(y)$ a $K(y)$ bola porovnaná s pozorovanými hodnotami; zhoda bola dobrá. Avšak optimalizačné funkcie sú platné len vtedy, ak sa vodný tok nemení. Tieto funkčné závislosti musia byt' reoptimalizované $\mathrm{v}$ prípade, ak sa zmení geometria priečnych rezov (napr. budovanie konštrukcií v inundovanom území), alebo pri zmene drsnosti (napr. rozdielne porasty); tieto zmeny musia byt' založené na nových meraniach vodných stavov alebo prietokov.

Formulácia optimalizačných kritérií, ktoré sú použité v tejto štúdii, je mimoriadne zložitá pre kanály so zloženým profilom hlavne pre neurčitost' spojenú so zmenou vodivostí čiastkových sekcií toku. Metóda vylučuje možnost' využitia súčinitel'ov drsnosti pre ustálené prúdenie (ktoré sú používané v rovniciach Chézyho a Manninga na výpočet sklonu čiary energie) pri výpočte neustáleného prúdenia v otvorených kanáloch.

Výpočet optimálnych parametrov transformácie povodňových vín bol možný, pretože boli $\mathrm{k}$ dispozícii výsledky presných meraní híbok na začiatku a na konci priameho úseku toku Main. Chyby meraných parametrov, spôsobené nepresnými metódami merania $\mathrm{v}$ teréne a malé množstvo meraní spôsobujú, že použivatel' sa pri optimalizácii spolieha skôr na niekol'ko povodňových udalostí, ako by mal získat' informácie len z udalosti jednej.
Určenie parametrov transformácie povodňových vín s využitím optimalizačných techník by malo vyústit' do úspory nákladov spojených s detailným terénnym prieskumom a malo by viest' $\mathrm{k}$ spresneniu numerických modelov toku. Napriek tomu optimalizačné metódy pravdepodobne nenahradia terénny výskum. Ich použitie je vhodné najmä pre prípady dlhých, relatívne stálych a málo dostupných priamych úsekov prirodzených vodných tokov.

\section{Zoznam symbolov}

$A$ - plocha priečneho rezu vodným prúdom $\left[\mathrm{m}^{2}\right]$,

$C_{q}$ - parameter v rovnici neustáleného prúdenia,

$f$ - koeficient trenia,

g - gravitačné zrýchlenie $\left[\mathrm{m} \mathrm{s}^{-2}\right]$,

$H$ - zvýšenie hladiny vody [m],

I - pomer sklonov čiar energie inundovaného územia a zloženého kanála,

$K$ - vodivost' časti toku $\left[\mathrm{m}^{3} \mathrm{~s}^{-1}\right]$,

$M_{f}$ - korekčný faktor pre moment v zloženej sekcii,

n - Manningov súčinitel' drsnosti,

$P$ - omočený obvod [m],

$Q-$ prietok $\left[\mathrm{m}^{3} \mathrm{~s}^{-1}\right]$,

$q$ - laterálny prietok $\left[\mathrm{m}^{2} \mathrm{~s}^{-1}\right]$,

$r$ - pomer hydraulických polomerov inundačného územia a kanála,

$S_{f}-$ sklon čiary energie $\left[\mathrm{m} \mathrm{m}^{-1}\right]$,

$S$ - sklon dna kanála $\left[\mathrm{m} \mathrm{m}^{-1}\right]$,

$t \quad-$ čas [s],

$W$ - šírka sub- sekcie [m],

$x$ - vzdialenost' pozdíž kanála [m],

$y$ - híbka prúdu [m],

$\beta-$ momentový korekčný faktor pre jednotlivú sub-sekciu,

$\lambda$ - koeficient zohl'adňujúci priečny mechanizmus prenosu momentu,

$\eta$ - koeficient zohl'adňujúci dynamiku vody $\mathrm{v}$ inundovanom území (flood-plain flow). 